\title{
Influence of the New Law on the Protection of Persons with Mental Disturbances on the Frequency of Involuntary Hospitalization at a Psychiatry Clinic of CHC Rijeka
}

\author{
Marija Vučić Peitl| ${ }^{1,2}$, Fadil Habibović ${ }^{1}$, Joško Prološčić ${ }^{1}$ \\ ${ }^{1}$ Department of Psychiatry, University Hospital Center, Rijeka, Croatia, ${ }^{2}$ Faculty of Medi- \\ cine Rijeka, University of Rijeka, Croatia
}

\begin{abstract}
The research was conducted at the Psychiatry Clinic of the Rijeka Clinical Hospital Center with the purpose of determining the impact of the new Law on the Protection of Persons with Mental Disorders (LPPMD) on the frequency of involuntary hospitalization. It covered two investigated periods. The first investigated period was the period of application of the old LPPMD from January $1^{\text {st }} 2012$ to December $31^{\text {st }} 2014$. The Second Investigated Period was the period of application of the New LPPMD from January $1^{\text {st }} 2015$ to December $31^{\text {st }} 2017$. In addition to comparing the frequency of involuntary hospitalization, the study includes diagnostic criteria, sociodemographic data, as well as means of arrival to the Clinic (police escort, ambulance, family) and the applied means of separation and restrictions. For the purposes of research, data from the Protocol on Involuntary Hospitalization, the History of Disease and the Integrated Hospital Information System were used. Analysis of the obtained results showed that there is no statistically significant difference in the frequency of involuntary hospitalization between the old and new LPPMD. However, observing the examined periods, we have noticed the tendency of increased frequency of involuntary hospitalization according to the new LPPMD. The obtained results of the research indicate that the majority of involuntarily hospitalized patients are male, 46.6 (SD 13.9) years old, unmarried, with completed high school education, unemployed, diagnosed with F20-F29- schizophrenia, schizotypal and delusional disorders and F10-F19- mental and behavioral disorders due to use of psychoactive substances involuntarily hospitalized and escorted by the police, with application of some means of separation and restriction.
\end{abstract}

Key words: involuntary hospitalization, frequency, impact, mental disturbances, human rights

Copyright (C) 2019 KBCSM, Zagreb

e-mail: alcoholism.kbcsm@gmail.com•www.http://apr.kbcsm.hr

Correspondence to:

Marija Vučić Peitl, PhD, assistant professor

Ludvetov breg 20, Rijeka

marijavp@gmail.com

\section{Introduction}

The existence of legislation on involuntary hospitalization and the application of restraining and separation measures is important in protecting the dignity of people with mental disturbances, as well as the dignity of 
medical professionals involved in the treatment, promotion and protection of mental health. It is also important for establishing whether the use of involuntary hospitalization is justified, especially in the context of the ever increasing procedures for determining liability in the implementation of compulsory hospitalization [1].

If we start from the assumption that people with mental disorders are often unable to decide by themselves on the treatment of their illness, we must accept the fact that persons with mental disorders are a particularly vulnerable group of patients who, due to the inability to exercise their rights, require adequate care for the protection and improvement of their mental health, as well as protection of their fundamental human rights [2].

The view on the issue of involuntary hospitalization can not be limited to the practice in the Republic of Croatia. It must also include the international legislation and conventions. The legislation of the Republic of Croatia, on which the Law on the Protection of Persons with Mental Disorders (LPPMD) is based, is ingrained in the Constitution of the Republic of Croatia and the generally accepted international standards and resolutions adopted by the World Health Organization, the Council of Europe and the United Nations General Assembly [2, 3].

When we analyze the international commitments reflected in Croatian legislation, we see that most of the legal and conventional provisions determine „danger to himself/ herself or others" as the basis for involuntary hospitalization. [2, 4]. The legislation emphasizes that this danger must be "current and intense" in order to prevent any misuse $[3,4]$.

In the legislation of the Republic of Croatia there is often a discrepancy between what is prescribed and what is actually applied, hence the adoption of the new LPPMD is another step towards protecting the vulnerable position of persons with mental disorders, in compliance with international and European standards. The new LPPMD not only provides protection of people with mental disturbances, it also tries to increase the level of their protection based on international laws and conventions $[4,5]$.

The adoption of the new LPPMD represents a new step towards harmonization of the legislative framework of the Republic of Croatia with international legal and conventional rights. One of the reasons for the introduction of the new LPPMD is the need for alignment with the new Criminal Law and the new Criminal Procedure Law, as well as the "processes of liberalization, transition and globalization in modern societies" [5, 6].

According to the new LPPMD a person with a mental disorder "can be involuntarily placed in a psychiatric facility if, due to a severe mental disorder, they seriously and directly endanger their own life and/or health, or the health of others; or if they were deemed incoherent during the criminal procedure due to severe mental disturbances, posing a threat to others, with court ordered involuntary hospitaliztion" $[4,6]$. Both incarnations of the LPPMD are based on the assumption that every person with a mental disorder has the right to protection and health care, and if placed in a psychiatric institution, they must have equal treatment conditions as patients in other health facilities [4, 7].

One of the most important changes in the new law is associated with the filing of complaints. According to the new LPPMD a person with a mental disorder can file an oral complaint which must be promptly addressed. A written complaint must be answered within eight days, which is a significant 
improvement compared to the old LPPMD. Concerning the above, it is important to note that according to the new LPPMD, every psychiatric institution must establish and keep records of the submitted complaints $[4,6]$.

The additional value of the new LPPMD is the limiting of the means of coercion. Unlike Art. 54 of the old LPPMD, according to which physical force could be applied in cases of "violent destruction or damage to someone's valuables", pursuant to Art. 61. of the new LPPMD measures of coercion can be applied only if a person "seriously and directly endangers himself/herself or others" $[4,6]$.

Bearing in mind that involuntary hospitalization, hospitalization without consent and the use of coercive means limit the fundamental constitutional and human right - the right to liberty, these procedures must be the focus of attention of the institutions and services which implement them. In this case, the State must provide clear protocols, guidelines and appropriate and effective protective mechanisms to prevent misuse $[6,8]$.

These protective mechanisms must reduce the possibility of conflict of interest and misuse during involuntary hospitalization, and provide proportionate measures adapted to individual circumstances, limited to the shortest possible period of time and subject to regular review of credibility by a relevant, independent and impartial body which in no case affect the rights and interests of an involuntarily hospitalized person [6].

Bearing in mind that involuntary hospitalization (forced detention and forced accommodation) is a mechanism of limiting a person's freedom; its compliance with the provisions of the Law, awareness of staff and patients and keeping quality medical documentation are all very important [6].
The New LPPMD, as the fundamental document for treatment of people with mental disturbances in the Republic of Croatia, further emphasizes the importance of informing the patients of their rights and of maintaining suitable and accurate medical documentation, especially in the areas of freedom restriction such as involuntary treatment or hospitalization [6].

In the analysis of the differences between the two Laws and the current situation in the health care system for the mentally ill special emphasis is placed on the financial component, with an additional provision stating that "budget restrictions in psychiatric institutions must not lead to violations of the patients' rights" [6].

For the sake of greater protection of those suffering from severe mental disturbances, the 72-hour deadline during which a psychiatrist could determine the reasons for release or involuntary detention in a psychiatric facility according to the old LPPMD, was shortened to 48 hours with the new LPPMD. This could affect the frequency of involuntary hospitalization $[4,9]$.

The research conducted at the Psychiatric Clinic of the Clinical Hospital Center (CHC) in Rijeka was designed to cover the period of application of the old and the new LPPMD, which is applied from January $1^{\text {st }} 2015$. By comparing these two investigated periods, apart from the sociodemographic and diagnostic criteria, we primarily wanted to assess the impact of the new LPPMD on the prevalence of involuntary hospitalization.

\section{Participants and methods}

All participants were involuntarily hospitalized patients treated at the CHC Rijeka Psychiatric Clinic during the past six years, divided into two study periods. 
The First Study Period (FSP) was during the final application of the old LPPMD between January $1^{\text {st }} 2012$ and December $31^{\text {st }}$ 2014 and the Second Study Period (SSP) was during the initial period of application of the new LPPMD between January $1^{\text {st }} 2015$ and December $31^{\text {st }} 2017$.

We used data from the Registry of Involuntary Hospitalization of the CHC Rijeka Psychiatric Clinic and data from the anamneses of involuntarily hospitalized patients saved in the Integrated Hospital Information System.

Descriptive data are presented in the tabular and graphic form of arithmetic means (AM) and standard deviations (SD), frequency and percentages. Chi-squared test was used in the variables of the categories for testing the significance of the difference; $t$-test was applied for the continuous variables.

The level of statistical significance was set at $95 \%(\mathrm{p}<0.05)$. All statistical analyzes were performed using the SPSS 16 statistical software (SPSS Inc., Chicago, IL, USA).

\section{Results}

Sociodemographic and clinical characteristics of participants

A total of 282 participants aged 18 to 80, involuntarily hospitalized at the CHC Rijeka Psychiatric Clinic between January $1^{\text {st }} 2012$ and November $31^{\text {st }} 2017$ participated in the study. Median age of the subjects was 46.6 (SD13.9). Most of the subjects were between 40 and 60 years old, with fewer younger and older participants (Figure 1).

The sample covered 122 (43.3\%) women and 160 (56.7\%) men (Figure 2).

$91(32.3 \%)$ participants were living in a marital union, 137 (48.6\%) were unmarried, $41(14.5 \%)$ were divorced and $13(4.6 \%)$ widowed (Figure 3).

$182(64.5 \%)$ of the surveyed had finished high school, 44 (15.6\%) completed some sort of higher education, $43(15.2 \%)$ completed elementary school, while 13 (4.6\%) were patients with uncompleted elementary school (Figure 4).

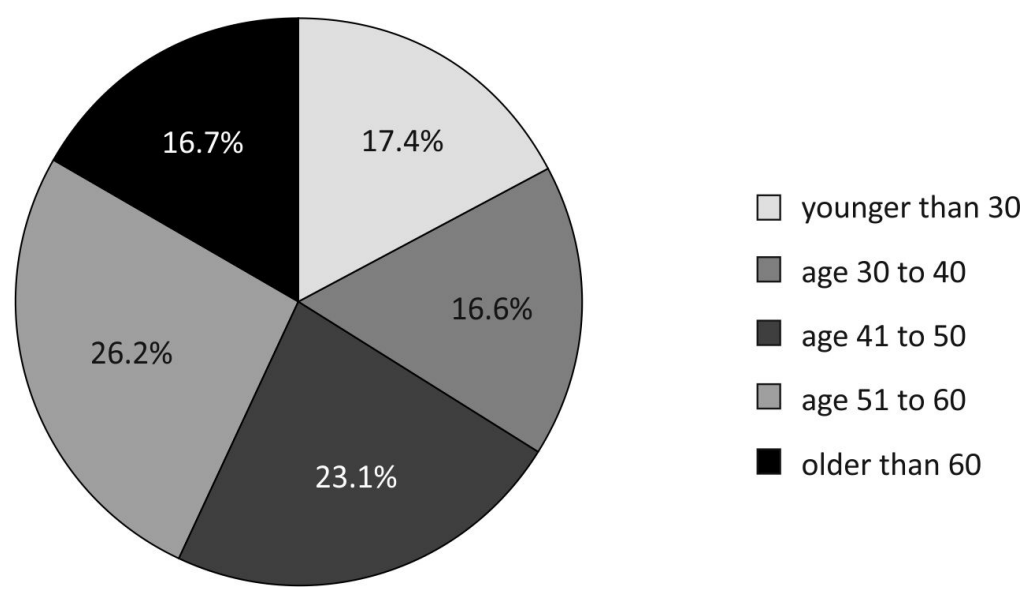

Figure 1. Distribution of participants according to age. 


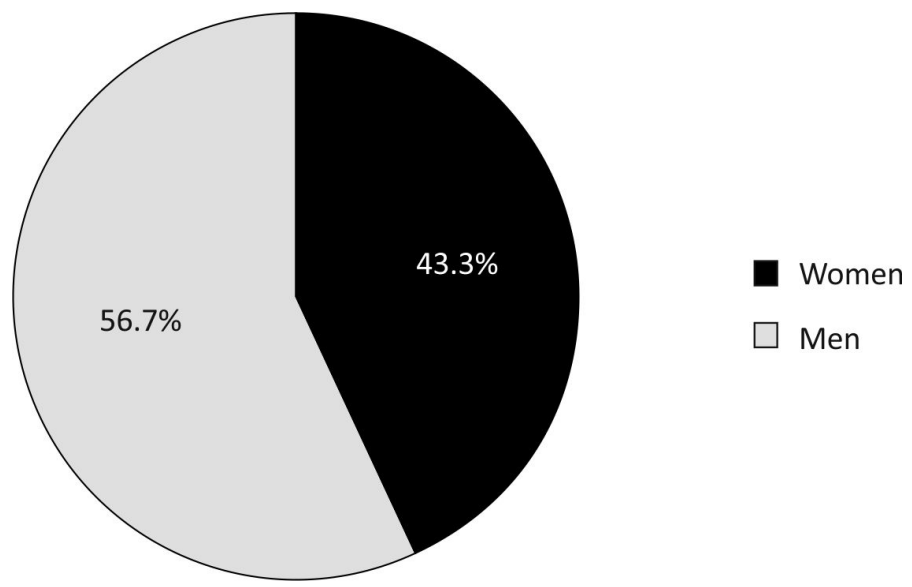

Figure 2. Distribution of participants according to gender.

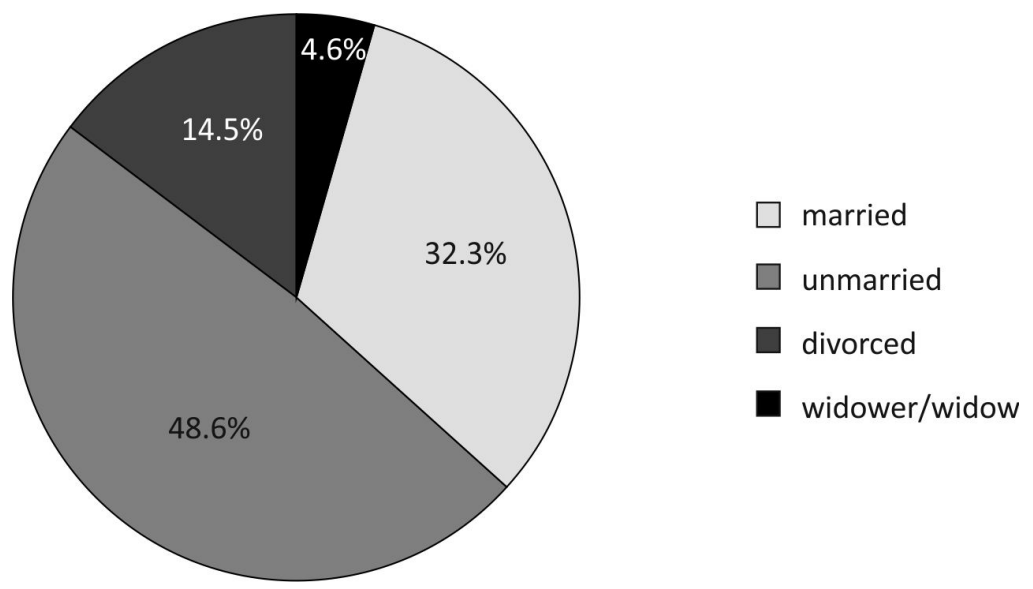

Figure 3. Distribution of participants according to marital status

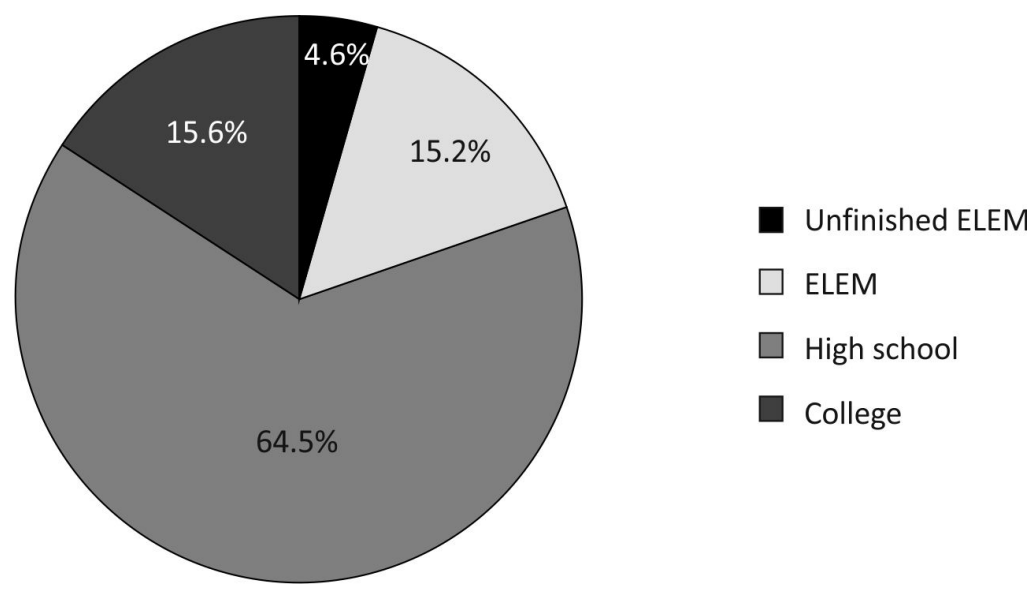

Figure 4. Distribution of participants according to level of education. 
$55(19.5 \%)$ of participants were employed, $124(44 \%)$ unemployed, $99(35.1 \%)$ retired and $4(1.4 \%)$ were still in school (Figure 5).

At the time of admission, most participants, $144(51.1 \%)$ received a diagnosis from the F20-F29 diagnostic group (schizophrenia, schizotypal disorders), followed by the F10-F19 group (mental disorders and behavioral disorders due to the use of psychoactive substances) (23.4\%), of which F10.0 (acute intoxication) was diagnosed in 78\% of cases, followed by the F00-F09 group (medical and symptomatic mental disorders) with $26(9.2 \%)$ patients; and the F30-F39 group (mood disorders) with $25(8.9 \%)$ patients. Other diagnostic groups were represented in a considerably lower percentage (Figure 6). A similar representation of some of the diagnostic categories was also observed at hospital discharge (Figure 7).

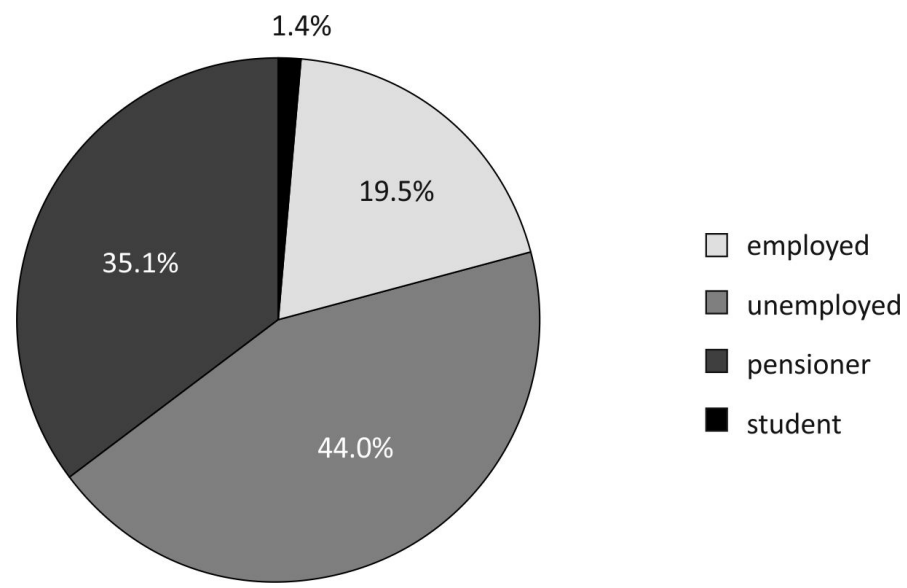

Figure 5. The distribution of participants according to work status.

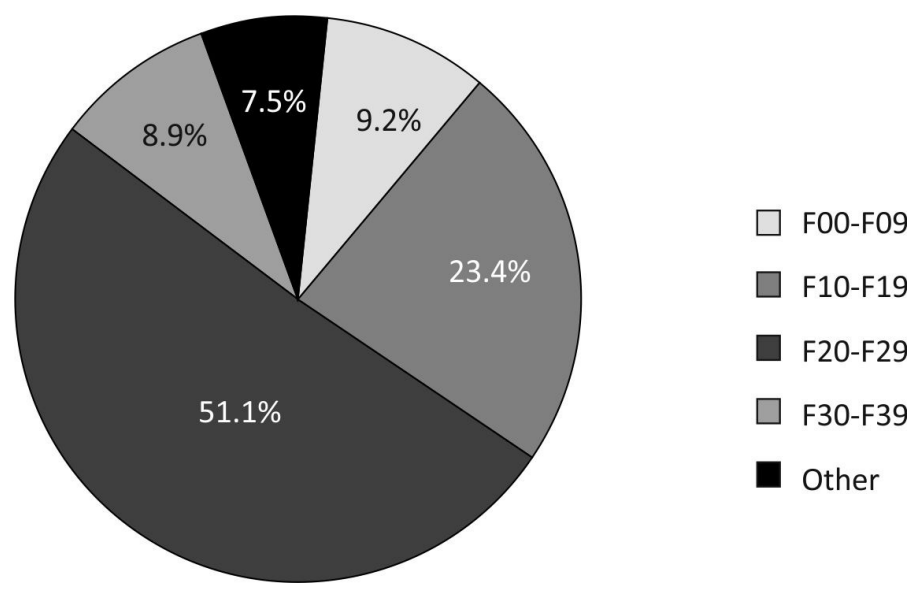

Figure 6. Distribution of participants according to their diagnostic group at hospital admission. 


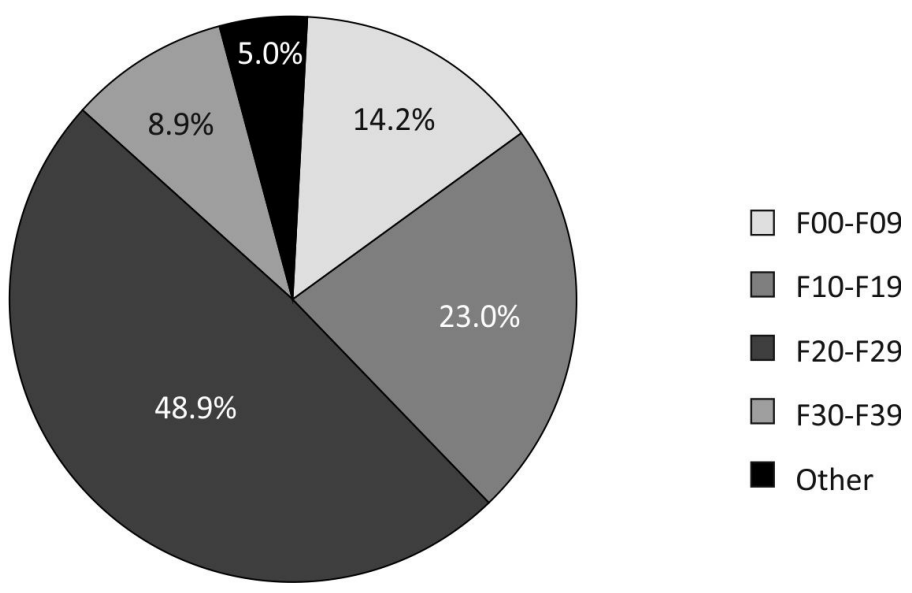

Figure 7. The distribution of participants according to their diagnostic group on hospital discharge.

\section{Comparison of the researched periods}

In FSP, 6050 patients were hospitalized, of which $133(2.2 \%)$ involuntarily, while in SSP 5854 patients were hospitalized, of which 148 (2.5\%) involuntarily, and this difference was not statistically significant $\left(\chi^{2}=1\right.$, 41; $\mathrm{p}>0.05$ ) (Table 1).
The difference in the age of patients hospitalized in FSP and SSP was not statistically significant ( $t=0.59 ; \mathrm{p}>0.05)$.

Patients hospitalized in FSP were not statistically different from patients hospitalized in SSP according to $\operatorname{sex}\left(\chi^{2}=0.53, \mathrm{p}>0.05\right)$ (Figure 8), marital status $\left(\chi^{2}=5.71, \mathrm{p}>0.05\right)$ (Figure 9), degree of education $\left(\chi^{2}=5.14\right.$;

Table 1. The number of involuntary hospitalizations compared to the total number of hospitalized patients in FSP and SSP

\begin{tabular}{lcccc}
\hline \multicolumn{2}{c}{ Men } & \multicolumn{2}{c}{ Women } \\
\hline Year & $\begin{array}{c}\text { Involuntary } \\
\text { hospitalization }\end{array}$ & $\begin{array}{c}\text { Number of } \\
\text { hospitalizations }\end{array}$ & $\begin{array}{c}\text { Involuntary } \\
\text { hospitalization }\end{array}$ & $\begin{array}{c}\text { Number of } \\
\text { hospitalizations }\end{array}$ \\
\hline 2012 & 16 & 945 & 24 & 899 \\
2013 & 31 & 1104 & 12 & 1006 \\
2014 & 26 & 1129 & 25 & 967 \\
Total & 73 & 3178 & 60 & 2872 \\
2015 & 33 & 1029 & 18 & 881 \\
2016 & 27 & 1016 & 23 & 915 \\
2017 & 27 & 1050 & 20 & 963 \\
Total & 87 & 3095 & 61 & 2759 \\
\hline
\end{tabular}




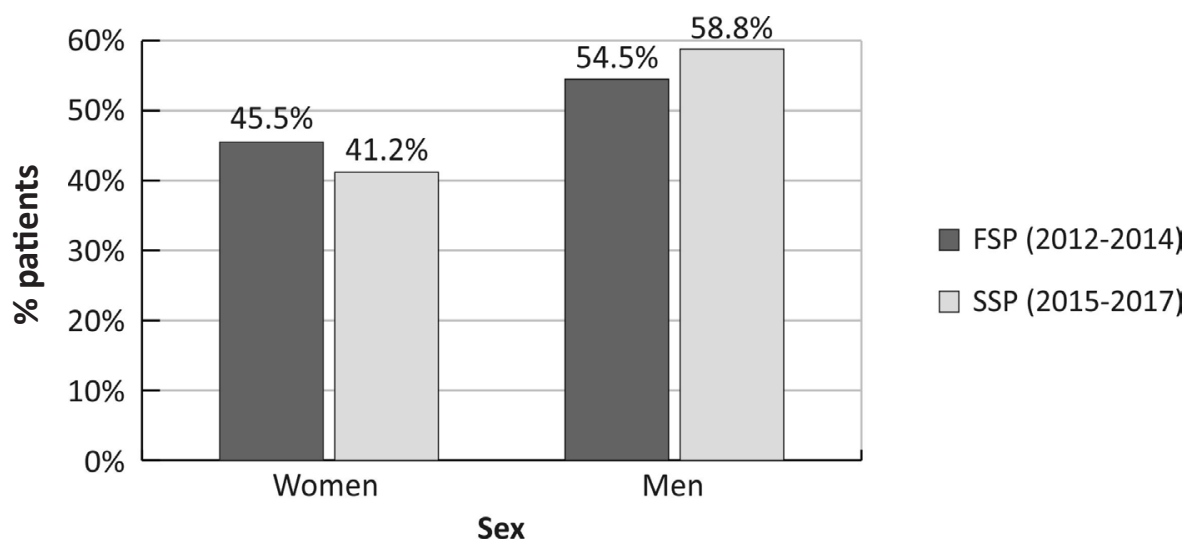

Figure 8. Differences among groups regarding sex of participants.

$\mathrm{p}>0.05)$ (Figure 10), or work status $\left(\chi^{2}=\right.$ 2.01; $\mathrm{p}>0.05)$ (Figure 11).

Patients hospitalized in FSP did not statistically differ from patients hospitalized in SSP according to the frequency of individual diagnostic groups at hospital admission $\left(\chi^{2}=\right.$ $5.76, \mathrm{p}>0.05)$, nor at hospital discharge $\left(\chi^{2}\right.$ $=4.69 ; \mathrm{p}>0.05)$. The most common diagnostic group for hospitalization in both periods was F20-F29, followed by F10-F19, F00-
F09, and other less common groups (Figure 12). A similar pattern of frequency of diagnosis was also observed at hospital discharge during both periods (Figure 13).

We established statistically significant differences regarding the incidence of individual diagnoses at admission $\left(\chi^{2}=14.35, \mathrm{p}<\right.$ $0.01)$ and at hospital discharge $\left(\chi^{2}=9.63, \mathrm{p}\right.$ $<0.05)$ related to sex in FSP. At admission and discharge, statistically significant num-

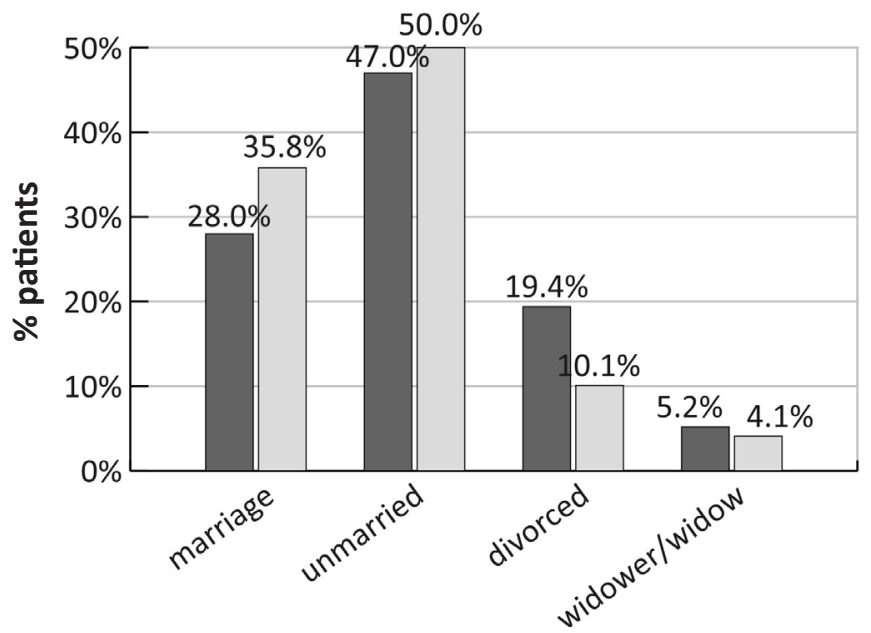

FSP (2012-2014)

$\square$ SSP (2015-2017)

Figure 9. Differences among groups regarding marital status. 


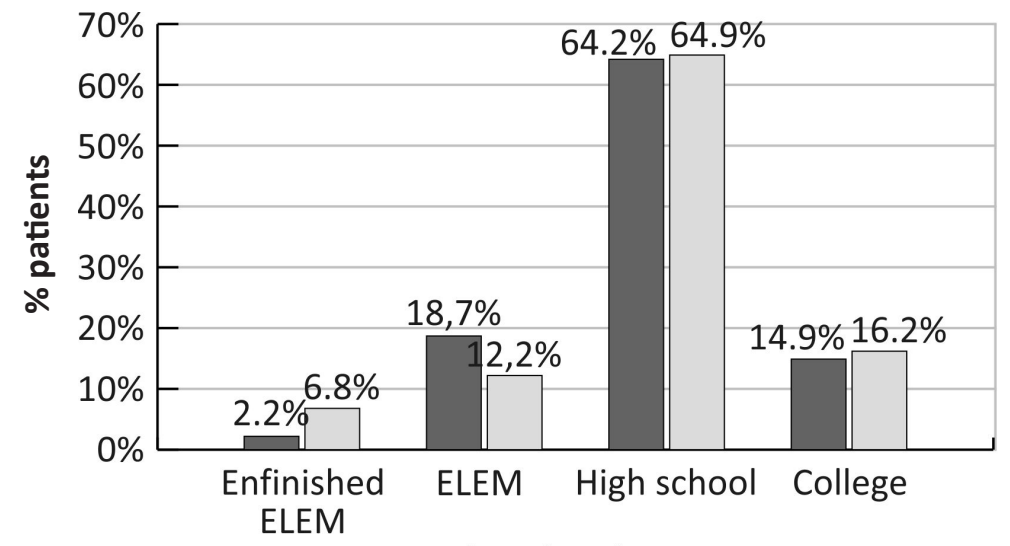

Education degree

Figure 10. Differences among groups regarding degree of education.

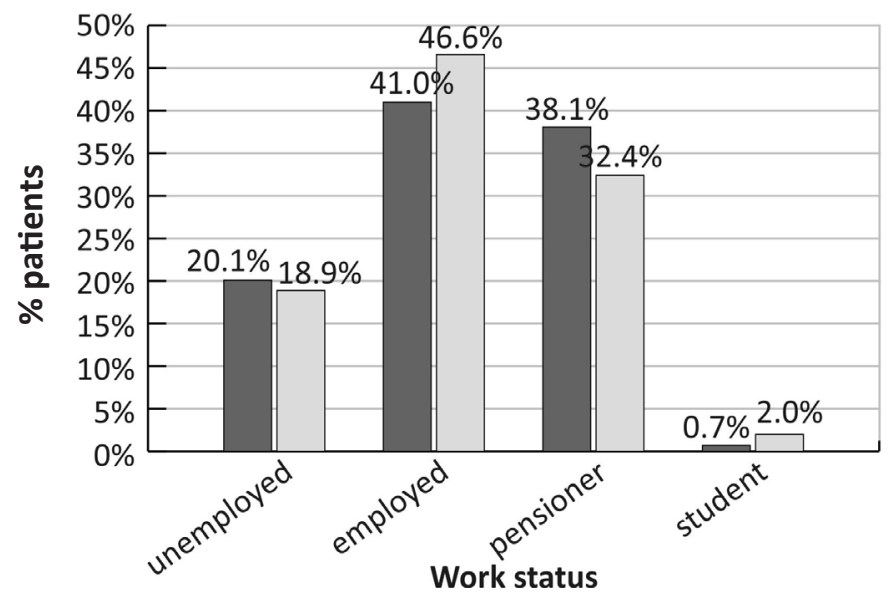

FSP (2012-2014)

SSP (2015-2017)

FSP (2012-2014)

$\square$ SSP (2015-2017)

Figure 11. Differences among groups regarding work status.

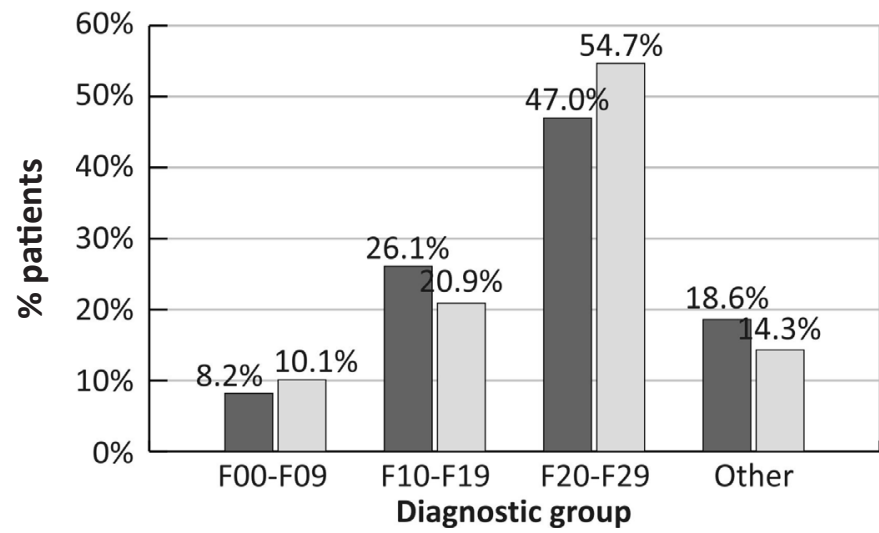

FSP (2012-2014)

$\square$ SSP (2015-2017)

Figure 12. Psychiatric diagnoses of patients at the time of hospitalization. 


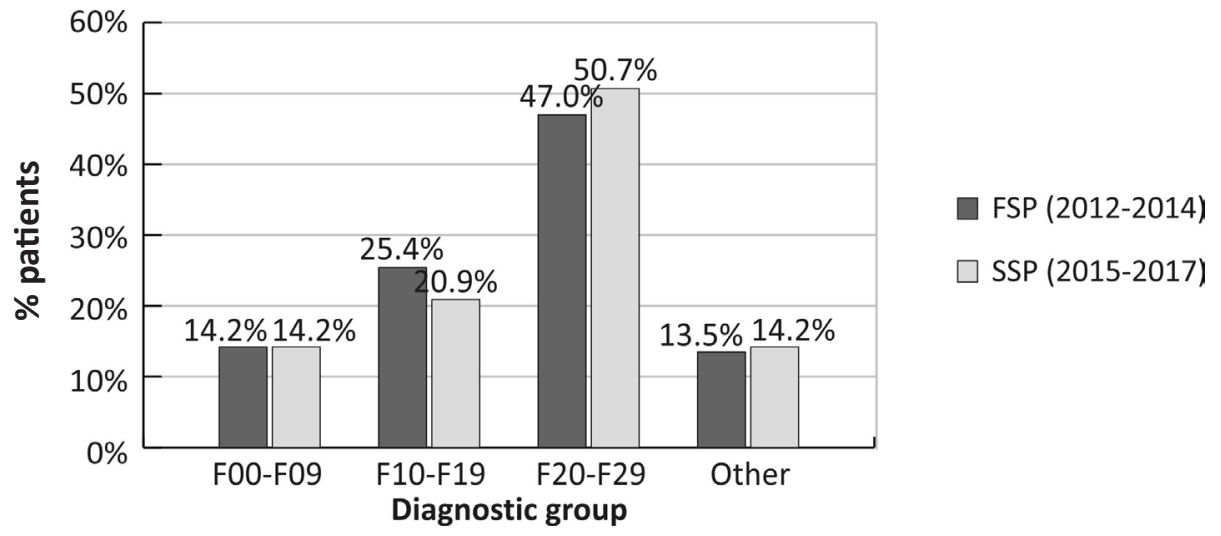

Figure 13. Psychiatric diagnoses of patients at the time of hospital discharge.

ber of males had a F10-F19 diagnosis, while the F00-F09 and F20-F29 diagnostic groups were significantly more represented in women. Other diagnoses were present approximately equally in both female and male participants (Figure 14).

In the SSP, we established statistically significant differences regarding the frequency of individual diagnoses with respect to sex at hospital admission $\left(\chi^{2}=8.29, \mathrm{p}<0.05\right)$, but not at hospital discharge $\left(\chi^{2}=4.73 ; \mathrm{p}>0\right.$, 05). When hospitalized, a significantly higher number of males had a F10-F19 diagnosis, while women were significantly more likely to be diagnosed with F20-F29. Diagnostic group F00-F09 and other diagnoses were represented approximately equally in both female and male participants (Figure 15).

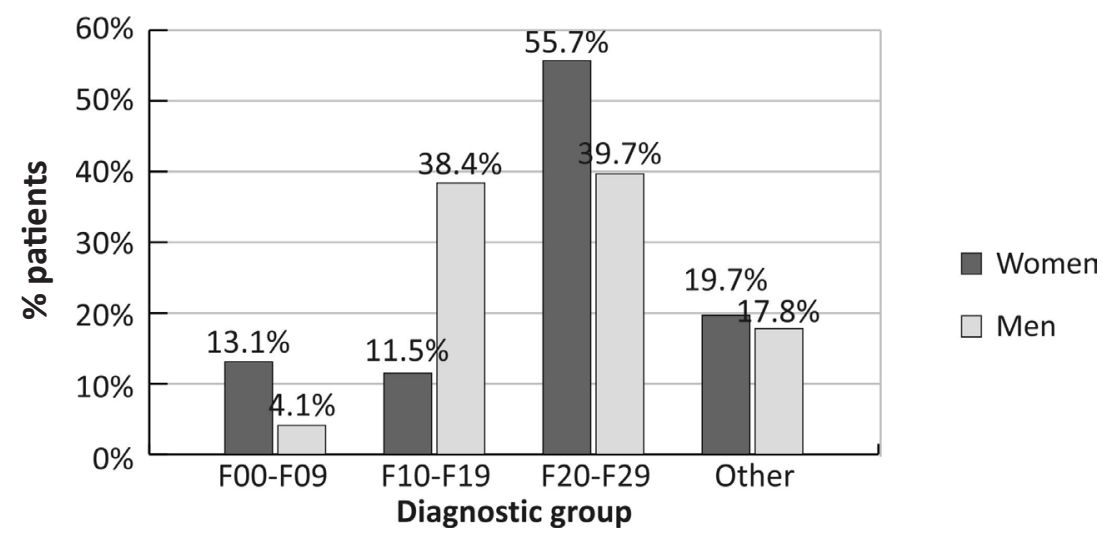

Figure 14. Differences in diagnoses between men and women in FSP. 


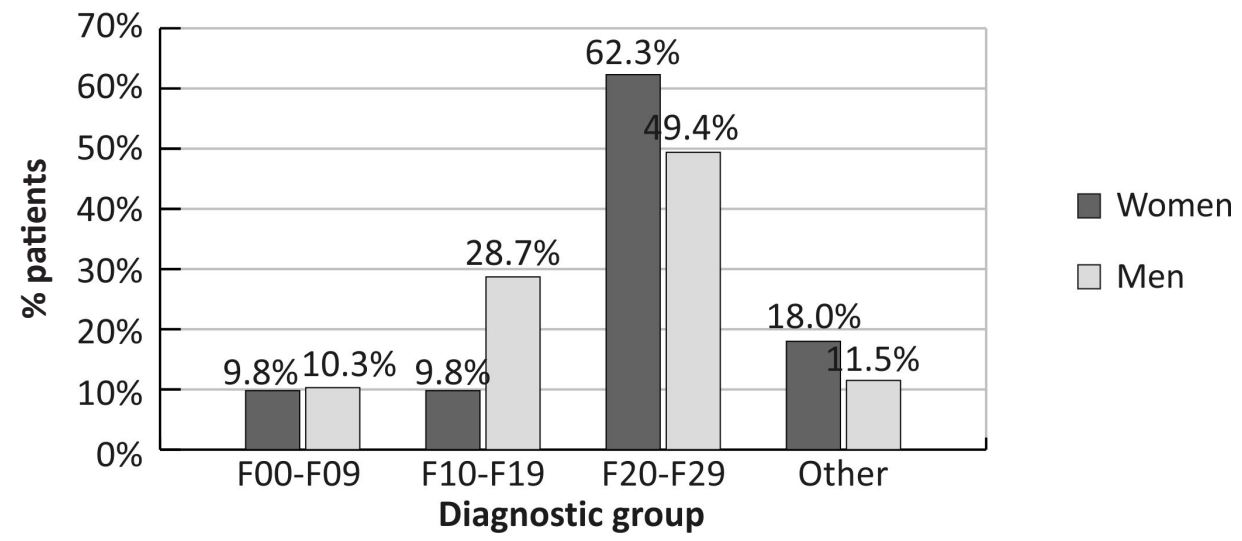

Figure 15. Differences in diagnoses between men and women in SSP.

\section{Means of arrival and isolation}

There was no statistically significant difference in the means of arrival of involuntarily hospitalized patients $\left(\chi^{2}=7.64, \mathrm{p}>\right.$ $0.05)$, nor in the use of separation and limiting means $\left(\chi^{2}=4.95 ; \mathrm{p}>0.05\right)$, with respect to the examined periods.

There was a statistically significant difference in the means of arrival of involuntarily hospitalized patients with regard to sex in FSP $\left(\chi^{2}=17.21, \mathrm{p}<0.05\right)$, whereas in SSP the difference was not statistically significant $\left(\chi^{2}=2.59 ; \mathrm{p}>0.05\right)$. In the FSP, a statistically significant number of males were accompanied by the police or the police and Emergency Medical Assistance (EMA), while women were usually alone or accompanied by family members (Figure 16).

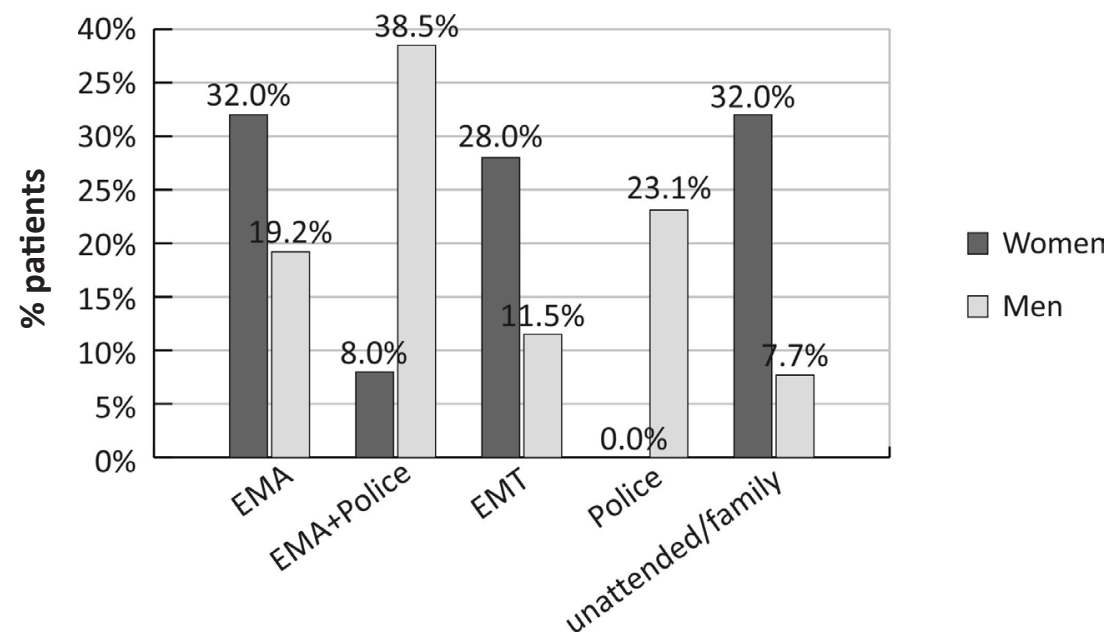

Figure 16. Differences regarding the means of hospital admission between men and women in FSP. 


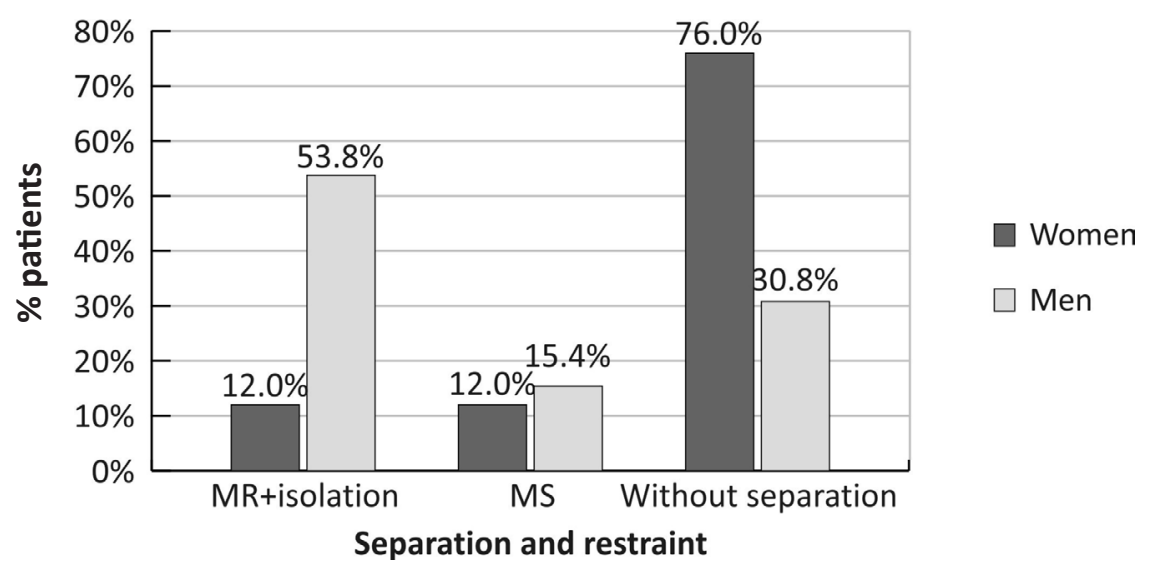

Figure 17. Differences regarding the use of separation and restraint between men and women in FSP.

There was a statistically significant difference regarding the use of means of separation and limitation of involuntarily hospitalized patients with respect to sex in FSP $\left(\chi^{2}\right.$ $=17.21, \mathrm{p}<0.05)$, whereas in SSP the difference was not statistically significant $\left(\chi^{2}\right.$ $=2.59 ; \mathrm{p}>0.05)$. In the SSP, a significantly higher number of women were hospitalized without isolation, while magnetic restraint straps and isolation were applied to a statistically significant number of men (Figure 17).

\section{Discussion}

Although the difference in the incidence of involuntarily hospitalization between the two examined periods was not statistically significant $\left(\chi^{2}=1.41, \mathrm{p}>0.05\right)$, it is apparent that the new LPPMD may affect the frequency of involuntary hospitalization in SSP.

According to the data from the county courts in Zagreb, Rijeka, Split and Osijek and the Croatian Ministry of Health [5], the frequency of involuntary hospitalization in psychiatric institutions according to the old
LPPMD at the Clinical Hospital Centers Osijek, Rijeka, Split and Zagreb in 2012, ranged between $0.36 \%$ in $\mathrm{CHC}$ Osijek and $2.20 \%$ in CHC Rijeka [5]. The above mentioned data indicate that the results obtained by county courts and the Ministry of Health are fully in line with the results obtained in our research related to FSP $(2.20 \%)$. Therefore, for the institutions with the incidence of involuntary hospitalization below 1\% a question arises whether all the persons with mental disorders were placed there willingly or were coerced [5]. According to the "Human Rights Report on Persons with Mental Disorders in Psychiatric Institutions" (2014) conducted under the National Preventive Mechanism, the share of "civil" involuntary hospitalization in the Republic of Croatia is $2.00 \%$ [6]. Given the data obtained in this research on the increased number of involuntarily hospitalized patients in SSP $(2.50 \%)$ this result is expected and the reasons are in the application of the new LPPMD (Article 27, NN 76/2014). Pursuant to article 27 of the new LPPMD, the timeframe during which a 
psychiatrist is obligated to inform the County Court of the reasons for involuntary detainment, is shortened from 72 hours of the old LPPMD (Article 25, NN111 / 97, 27/98, $128 / 99$ and $79 / 02)$ to 48 hours according to the new LPPMD (Article 29; NN 76/2014) $[4,7]$. The reasons for increased frequency of involuntary hospitalization can also be found in the amended procedure by which the court decides on involuntary placement (Article 37, NN 76/2014) in a verbal hearing of an involuntarily detained person at a psychiatric institution, with a legal representative or a lawyer, or if necessary, other persons who might influence the court's decision [4]. The reported rate of involuntary hospitalization in European countries is 5.00\% in Belgium, $12.50 \%$ in France, $4.60 \%$ in Denmark and $21.60 \%$ in Finland [10]. According to Gultekin and associates, the incidence of involuntarily hospitalization in Turkey is $13.10 \%$ [11].

A new legal proposal is expected to equalize the court practice in the Republic of Croatia. By specializing judges and attorneys dealing with LPPMD - related cases, and with long-term psychiatrists' experience, the criteria for compulsory hospitalization of persons with mental disorders and the application of the new LPPMD will be equated to diminish the difference in the frequency of involuntary hospitalization present during the application of the old LPPMD [5].

According to the results of our research, the median age of respondents was 46.6 years and they were predominantly male (57\%). The obtained results are congruent with the previously conducted research in the Republic of Croatia and worldwide. According to the six-month follow-up study conducted at the Vrapče Psychiatric Clinic, the median age of participants was 45.3 years, while $55.92 \%$ $[12,13]$ of the participants were male. The research conducted with five-year follow-up revealed that most of the involuntarily hospitalized patients are men (57.5\%) [14]. So far, the available research in Croatia and worldwide shows the link between compulsory hospitalization and sex [13]. Thus, according to a survey conducted in Turkey, 72.7\% of involuntarily hospitalized are men [11]. Studies in the United States and Norway also link male sex with the incidence of involuntary hospitalization [15-16]. When comparing FSP with SSP we did not find statistically significant differences in terms of $\operatorname{sex}\left(\chi^{2}\right.$ $=0.53, \mathrm{p}>0.05)$. However, the results of studies conducted so far in Croatia, USA and some European countries indicate that the male sex can certainly be considered as a predictor of involuntary hospitalization $[17,18]$.

Other sociodemographic features obtained by this research regarding marital status, education and work status, are in line with the so far conducted research and expectations [12]. In terms of education status, most participants had completed secondary school (64.5\%); 44\% were unemployed and 35.1\% were retired. Only $19.5 \%$ of the participants were employed. According to Žaja's survey, the share of involuntarily hospitalized persons with completed secondary school was $40.79 \%$, which is similar to our results. Only $21.7 \%$ of involuntarily hospitalized patients were employed [12]. The results of both researches indicate that one of the fundamental human rights, "the right to work", is jeopardized and difficult to attain for psychiatric patients, despite the existing projects in the Republic of Croatia promoting the employment of persons with psychological disorders [19, 20].

According to the results of the survey, the most commonly diagnosed group in compulsively hospitalized patients in both examined 
periods is F20-F29, followed by F10-F19, then F00-09, and then other low-incidence groups. By comparing the incidence of the individual diagnostic groups of involuntarily hospitalized patients, statistically significant differences were observed regarding hospital admissions and discharge between sexes in FSP. At admission and discharge from hospital, statistically significant number of males had F10-F19 diagnosis, while women were significantly more represented in the diagnostic groups F00-F09 and F20-F29. The SSP showed statistically significant differences in the frequency of individual diagnoses related to sex at hospital admission, but not at discharge. When hospitalized, a significantly higher number of males had a F10-F19 diagnosis, while women with F20F29 were significantly more likely to be diagnosed. This result confirms a statistically significant difference between involunarily hospitalized patients in the diagnostic group F10-F19 (mental disorders and behavioral disorders due to the use of psychoactive substances) in relation to sex in both examined periods, studied by the relevant research conducted on this topic.

When analyzing the obtained results and comparing them with relevant research, we can safely state that the highest number of involuntarily hospitalized patients belongs to the F20-F20.9 group [13, 14]. According to the aforementioned studies, the second most represented group of involuntarily hospitalized patients is the F10-F19 diagnostic group [14]. In our research we have established that the diagnosis from this group of diagnoses (F10-F19) is more frequent in men, although its statistical significance is established only in the SSP.

This research has revealed a statistically significant difference regarding the means of arrival of involuntarily hospitalized patients in terms of sex in FSP. In SSP, a statistically significant number of males were accompanied by the police or the police and EMA, while women were usually alone or accompanied by family members. The circumstances of the arrival at the psychiatric facility described in the researches showed that $27.6 \%$ of patients were escorted by the EMA and the police, while $3.3 \%$ of patients arrived with family, the EMA and the police [12]. Only $1.3 \%$ of patients arrived with the police. Summing up these results, we conclude that up to $32.2 \%$ of patients arrived at a psychiatric institution with police escort. While our research has shown a different way of hospitalization in relation to sex, the results indicate that $38.5 \%$ of men and $8 \%$ of women are involuntarily hospitalized when accompanied by the EMA and police, while $23.1 \%$ male patients were accompanied by the police only. These data indicate that the incidence of involuntary hospitalization is much higher in male patients who have been admitted to a psychiatric institution accompanied by the EMA and the police (38.5\%), or police only $(23.1 \%$ ), representing $61.6 \%$ of all involuntary hospitalizations. Therefore, additional research is necessary to identify the actual causes of involuntary hospitalization. It is necessary to ascertain whether "the fear of an agitated patient and the police escort" is an additional reason for unnecessary involuntary hospitalization.

In the application of the means of separation and limitation on the compulsory hospitalized patients according to sex, a statistically significant difference was found in FSP, while the SSP difference was not statistically significant. In the FSP, a significantly higher number of women were hospitalized without isolation, while magnetic strains and isolation 
were applied to a statistically significantly higher number of males.

From the results we conclude that the male sex poses a significantly higher risk factor for the use of separation and means of limitation, or just separation. In $53.8 \%$ of men in FSP, a separation and limitation measure (isolation + magnetic strip) was applied, while limiting measures (magnetic strips) were applied in $15.4 \%$. The need to apply separation and restriction measures in female subjects was significantly lower. According to the results of our research, in $76 \%$ of compulsory hospitalized women, no means of separation and / or restriction have been applied. We believe that this issue has been underestimated and that involuntary hospitalization in those suffering from mental disorders who were detained by the police should be the subject of future research.

\section{Conclusion}

Our results indicate that there is no statistically significant difference in the incidence of involuntary hospitalization according to the old and new LPPMD. However, observing the examined periods we have noticed a tendency for increased frequency of involuntary hospitalization according to the new LPPMD. Most of the involuntarily hospital-

\section{References}

1. Goreta M. Primjena sile u psihijatrijskom tretmanu. Zagreb, Croatia: Naklada Zadro; 2009.

2. Kozumplik O. Cimbenici u primjeni mjera prisilnog liječenja osoba s duševnim smetnjama. Zagreb, Croatia: Sveučilište u Zagrebu, Medicinski fakultet: Disertacija; 2005. ized patients were male, the median age was 46, unmarried, with a high school education and unemployed. The most frequent diagnostic group of involuntarily hospitalized patients was the F20-F29 diagnostic group (schizophrenia, schyzotypal disorders), followed by the F10-F19 group (mental and behavioral disorders caused by the use of psychoactive substances). In the first and second examined period, significantly higher number of males had a F10-F19 diagnosis at the time of hospital admission. Furthermore, significantly higher number of males were brought to a psychiatric institution by the police in the first examined period. In the FSP, separation and restriction were used significantly more in involuntarily hospitalized males. In the FSP a significant number of women were involuntarily hospitalized without the use of separation means.

\section{Acknowledgments}

Renewed part of a graduate thesis study of the Graduate University Study of Nursing - Promotion and Protection of Mental Health.

\section{Conflict of interest}

None to declare.
3. Goreta M, Turković K, Jukić V. Psihijatrija i zakon. Zagreb, Croatia: Psihijatrijska bolnica Vrapče; 1998.

4. Zakon o zaštiti osoba s duševnim smetnjama. Zagreb, Croatia: NN 76/14; 2014.

5. Grozdanić V, Tripalo V. Novosti u zakonu o zaštiti osoba s duševnim smetnjama. Hrvatski ljetopis za kazneno pravo i praksu. 2013;:23:795-820. 
6. Republika Hrvatska, pučki pravobranitelj. Ljudska prava osoba s duševnim smetnjama u psihijatrijskim ustanovama u okviru djelovanja Nacionalnog preventivnog mehanizma u 2014. godini. Zagreb, Croatia: Pučki pravobranitelj; 2015.

7. Zakon o zaštiti osoba s duševnim smetnjama. Zagreb, Croatia: NN 111/97, 27/98, 128/99, 79/02; 2002.

8. The Constitution of the Republic of Croatia. Zagreb, Croatia: NN 41/01; 2001.

9. European Court of Human Rights. The case of M.S. versus the republic of Croatia. Strasbourg: European Court of Human Rights, European Council; 2015.

10. Salize HC, Dressing H. Epidemiology of involuntary placement of mentally ill people across the European Union. Br J Psychiatry. 2004;184:163-8.

11. Gültekin BK, Çelik S, Tihan A, Ali Fuat Beşkardeş AF, Sezer U. Sociodemographic and clinical characteristics of psychiatric inpatients hospitalized involuntarily and voluntarily in a mental health hospital. Noro Psikiyatr Ars. 2013;50:216-21.

12. Žaja N. Prisilno zadržavanje i prisilni smještaj (šestomjesečno praćenje u Klinici za psihijatriju Vrapče.). Zagreb, Croatia: Sveučilište u Zagrebu, Medicinski fakultet: Disertacija; 2014.

13. Folnegović-Šmalc V, Uzun S, Ljubin T. Sex-specific characteristics of involuntary hospitalization in Croatia. Nord J Psychiatry. 2000;54:55-9.
14. Potkonjak J, Karlović D. Sociodemographic and medical characteristics of involuntary psychiatric inpatients-retrospective study of five-year experience with Croatian Act on Mental Health. Acta Clin Croat. 2008;47:141-7.

15. Hustoft K, Larsen TK, Austed B, Joa I, Johannessen JO, Ruud T. Predictors of invountary hospitalizations to acute psychiatry. Int J Law Psychiatry. 2013;36:136-43.

16. Sanguineti VR, Samuel SE, Schwartz SL, Robeson MR. Retrospective study of 2,200 involuntary psychiatric admissions and readmissions. Am J Psychiatry. 1996;53:392-6.

17. Kozumplik O, Jukić V, Goreta M. Involuntary Hospitalizations of Patients with Mental Disorders in Vrapče Psychiatric Hospital: Five Years of Implementation of the First Croatian Law on Protection of Persons with Mental Disorders. Croat Med J. 2003;44:601-5.

18. Malla A, Norman RM, Helmes E. Factors associated with involuntary admission to psychiatric facilities in Newfoundland. CMAJ. 1987, 136:1166-71.

19. Konvencije o pravima osoba s invaliditetom. Zagreb, Croatia: NN 6/07; 2007.

20. Štrkalj-Ivezić S, John N, Sučec J, Grgin M, Hali M. Zapošljavanje osoba sa psihičkom bolesti. Zagreb, Croatia: Udruga Svitanje; 2011.

\section{Utjecaj novog Zakona o zaštiti osoba s duševnim smetnjama na učestalost prisilne hospitalizacije na Klinici za psihijatriju KBC Rijeka}

Sažetak- Istraživanje je provedeno na Klinici za psihijatriju Kliničkog bolničkog centra Rijeka sa svrhom utvrđivanja utjecaja novog Zakona o zaštiti osoba s duševnim smetnjama (ZZODS) na učestalost prisilne hospitalizacije. Obuhvaćalo je dva istraživana razdoblja: Prvo istraživano razdoblje u periodu primjene starog ZZODS-a od 1. siječnja 2012. do 31.prosinca 2014. godine i drugo istraživano razdoblje u periodu primjene novog ZZODS-a od 1.siječnja 2015. do 31.prosinca 2017. godine. Uz uspoređivanje učestalosti prisilne hospitalizacije, istraživanje obuhvaća dijagnostičke kriterije, sociodemografske podatke kao i načine dolaska na Kliniku (policija, Hitna medicinska pomoć, obitelj) te primjenu sredstava izdvajanja i ograničavanja. Za potrebe istraživanja korišteni su podatci iz Protokola prisilnih hospitalizacija, Povijesti bolesti i Integriranog bolničkog informacijskog sustava. Analizom dobivenih rezultata utvrđeno je kako ne postoji statistički značajna razlika u učestalosti prisilnih hospitalizacija prema starom i novom ZZODS-u iako, kada promatramo ispitivana razdobl- 
ja, možemo uočiti tendenciju povećanja učestalosti prisilnih hospitalizacija prema novom ZZODS-u. Prema rezultatima istraživanja većina prisilno hospitaliziranih pacijenata su osobe muškog spola, prosječne dobi 46,6 (SD 13,9) godina, neoženjeni, završene srednje škole, nezaposleni, s dijagnozom iz skupine F20-F29- Shizofrenija, poremećaji slični shizofreniji i sumanuta stanja i F10-F19- Mentalni poremećaji i poremećaji ponašanja uzrokovani upotrebom psihoaktivnih tvari, prisilno hospitaliziranih u pratnji policije, te su nad njima bila primijenjena neka od sredstava odvajanja i ograničavanja.

Ključne riječi: prisilna hospitalizacija, učestalost, utjecaj, duševne smetnje, ljudska prava 